BLS 35, No 1 2009. DOI: http://dx.doi.org/10.3765/bls.v35i1.3596

(published by the Berkeley Linguistics Society and the Linguistic Society of America)

\title{
As Long As You're not Effeminate and Fat: Perpetuating the Heteronormative Discourse in Personal Ads of Serbian Gay Youth on the Web
}

\author{
KSENIJA BOGETIĆ \\ University of Novi Sad
}

\section{Introduction}

Sociolinguistic investigation of questions related to gender and sexuality has recently gained much scholarly attention. The novel poststructuralist voices have brought some significant changes in the field, including the shift away from the concept of binary differences and the adoption of a wide range of third-wave feminist and queer stances.

Research on language and sexuality has mainly focused on sexually marginalized groups and their stigmatization in the heteronormative society. In response to this tendency, the present paper aims to explore the discursive manifestations of the marginalization of effeminate gay men within the gay community itself, a phenomenon which has received less attention in research. The relations of language and sexuality, such as described in this paper, should at the same time be viewed as indicative of a more general relationship between language and social meaning. I show how Serbian gay teenagers draw on shared cultural knowledge and ideological resources available in their community to construct sexual and social identities modelled on the basis of socially desirable masculine identities. The study reveals how hegemonic discourses of masculinity and heterosexuality are perpetuated, rather than challenged, through linguistic practices that index personal and group identities. At a broader level, I argue that it is in this way that a subordinated culture allows dominant discourses to survive and its own marginality to be upheld.

\section{Sexuality, Identity, Language}

Within the past two decades, the field of language and sexuality has emerged as a significant area of inquiry in socioculturally oriented scholarship. In earlier gender research sexuality was mainly subsumed into gender, but it has more recently come to be recognized as a separate theoretical concept (Bucholtz and Hall 2004). The two concepts are, nevertheless, intricately related, sexuality being closely tied 


\section{Ksenija Bogetić}

to prevalent ideas of masculinity and femininity. Research on language and sexuality mainly deals with sexually marginalized groups (e.g. gay, transgender), exploring identities largely ignored in the existing literature. Rather than describing any predefined gay or lesbian language, it investigates the multiplicity of ways that such groups use language to construct various identities

A recent approach to the investigation of language and sexuality is known as queer linguistics (Barrett 1997, 2002; Livia 2002). The approach combines insights and models from sociolinguistics, anthropology, queer theory, postfeminist gender theory and many other linguistic and non-linguistic disciplines, although its agenda and methodology are yet to be fully defined. Importantly, queer linguistics draws on one of the paramount assumptions in Queer Theory, the idea that meaning is unfixed and constantly subject to reformulation. As Barrett (2002) points out, such a notion contributes to linguistic investigation in general, by recognizing categories as ideological constructs that are produced by social discourse and not extant per se. This could clearly benefit research in sociolinguistics, by revealing how the relation between particular variables and social meaning is formed, instead of presenting catalogues of correlational facts, which is coming to be viewed as one of the principal weaknesses of traditional sociolinguistic approaches. Moreover, the approach allows for the introduction of gender identities that have been neglected in traditional approaches and subsumed into the binary sex and gender models (Barrett 2002).

Questions of identity have been of primary interest in the development of queer linguistics. This approach rejects the essentialist views of identity as a fixed and predefined psychological construct. Rather, identity is seen in light of social constructionism, as a fluid and ever-changing process that takes place in concrete interactional situations. In the creation and negotiation of identity, language plays a key role; the centrality of language in the study of identity has nowadays been firmly established in fields as diverse as anthropology, sociology, linguistics, literature and history (De Fina et al. 2006). Discussing the relationship between language and sexual identity in this paper, I adopt the social-constructionist conceptions of identity and focus on its discursive manifestations in local contexts, rather than its relations to any predefined 'gay language.'

A central notion in the study of identity is the semiotic concept of indexicality. Indexical signs are linguistic structures that index (or point to) aspects of the social context. Linguistic resources are usually not directly correlated with social categories, but index them indirectly, through some other social meaning (Ochs 1992). For example, a particular linguistic form may index stances of politeness or deference, which are in some communities ideologically associated with female identity. Thus, in the relationship of language and social identity there is no simple direct mapping; rather, the relationship is mediated by indexicality, as particular social identities come to be ideologically associated with particular linguistic forms.

Importantly, then, indexicality involves the ability of linguistic resources to evoke entire systems of meaning such as ideologies, social representations and 


\section{Heteronormative Discourse in Personal Ads}

social roles (De Fina et al. 2006) as well as discourses shared within a culture. The framework is of great significance in queer linguistics, as it allows for the discovery and fuller understanding of pre-existing norms and expectations about sexual identity. An important question for queer linguistics is how the construction and negotiation of nonhegemonic sexual identities is affected by social discourses and how it reflects social discourses. This inevitably involves the study of power relations. Bucholtz and Hall (2004) note that a significant feature of queer linguistics is that it allows the exploration of sexual ideologies, practices and identities while keeping in mind the power relations in which they are embedded. Pertaining to issues of normative sexuality, the term 'hegemony', rather than direct 'power', seems more appropriate. As Kiesling (2006) points out, drawing on Gramsci (1994), hegemony allows dominant social institutions to survive through less obvious means, such as controlling the underlying ideologies in a society. The hegemony of masculinity and heterosexuality, though in many cultures not overtly expressed or imposed, lives on through discourses that are produced and re-produced in a community.

In this paper I am interested in hegemony and power relations within the gay community itself, among its very members, and the ways in which such relations are linked to the dominant social and cultural notions about sexuality. I demonstrate how power relations centred around the concepts of appropriate masculinity exist here as well, reflecting the predominant views among Serbian youth of what it means to be a man.

\section{GaySerbia}

The data used in this study consist of 140 personal ads from the GaySerbia web portal. The study focuses on gay youth identities, so only ads written by young men aged 16 to 19 , mostly high-school students, were considered. The ads were collected during the first part of 2008, though many might have been posted on the website some months earlier.

GaySerbia is the most popular dating website of the Serbian LGBT community. Apart from the personal ads section, visitors can communicate in a chat room and on the forum. The site also offers news and articles on current events or curiosities related to queer issues. The ads, however, are among the central elements of the site and even graphically take a particularly prominent place on the home page.

Given the situation in Serbia, the internet offers a safe and significant site of communication for gay men. Despite certain changes that have taken place in the past ten years, public discourse in Serbia still abounds in homophobic prejudice, leading to discrimination of these groups, as well as to physical danger. Judging by the number of the ads on the portal, people of the studied age are among the most frequent visitors of the site, which is not surprising given the predominant attitude towards homosexuality in the youth culture in Serbia. High-school environment tends to embrace the traditional values of masculinity and toughness in men, and the practice of occasional 'pairing off' in heterosexual couples is a 


\section{Ksenija Bogetić}

prerequisite to gaining acceptance and social status. Open statements of homosexuality normally result in social exclusion, stigmatization and physical abuse by peers. In such circumstances, the Internet provides a safe environment in which to freely express one's identity and search for solidarity, affiliation or relationships.

However, the internet offers a specific place for identity construction, especially when teenagers are concerned. What is attractive for young people in computer-mediated communication is that they can establish online identities that reflect their desired personae and the ways in which they wish to be perceived by others. Moreover, the possibility of staying anonymous makes the online space much more suitable for exploring one's sexuality and some issues that would probably never be raised in face-to-face communication. This growing medium of communication is changing the ways we view interaction and will possibly have some impact on identity scholarship as well, as identity becomes more veiled online, with notions of fluidity and performativity even more emphasised.

\section{Upholding Hegemonic Masculinity}

One aspect of identity that a large majority of the ad writers commonly orient to is possession or appreciation of the typical masculine traits. Masculinity tends to be stressed as the primary quality possessed and searched for in the ideal partner:

Virag91: Osim što sam zgodan, inteligentan sam, duhovit, otvorenih shvatanja i totalno nefem. Tražim muškarca koji dobro izgleda, koji nije feminiziran i promiskuitetan već pravi muškarac sa svim macho osobinama.

'Virag91: Apart from being handsome, I am intelligent, funny, openminded and totally non-fem. I am searching for a man who is goodlooking, who is not effeminate and promiscuous, but a real man with all the macho qualities.'

This is a typical example of a GaySerbia ad. After a brief self-description, the author goes on to list the desired qualities of a partner, primarily centred around good physical appearance and masculinity, while effeminacy is directly excluded. By describing his preferred partner as 'a real man with all the macho qualities', Virag relies on shared cultural knowledge that he assumes must allow the readers to understand what phrases like a real man and macho qualities signify and what their social meaning is.

Discourses of masculinity have been widely studied in the past two decades. The notion of hegemonic masculinity, first introduced by Connel $(1987,1995)$ has prompted much research on power relations and gender ideologies. However, most studies observe men and masculinities in sexually dominant (heterosexual) groups, men who claim the right to masculinity as an expected aspect of their identity. This paper, conversely, analyzes the discourses of masculinity present in the construction of sexually marginalized (homosexual) identities, showing how the construct of hegemonic masculinity is perpetuated here in similar ways. 


\section{Heteronormative Discourse in Personal Ads}

Sexual and gender presentations in the ads project the ideology and expectations of the Serbian high-school community. Traces of the heteronormative discourse can thus be observed even within this gay community. The common apologetic stance with which the ad writers repeatedly stress that they are 'sane' and 'normal men' although they prefer partners of the same sex, solidifies the idea that heterosexuality is unquestionably the norm, while homosexuality is a marked category that needs to be accounted for. It is not uncommon for the authors to directly define themselves as normal because of having had heterosexual relationships, as illustrated in the following ad:

(2) Miško: Normalan sam dečko, imao sam devojke, ali bih voleo i ovako nešto da probam. Nikad nisam probao ali me zanima.

'Miško: I'm a normal guy, I've had girlfriends, but I would like to try something like this as well. I have never tried it but I am interested.'

Formulating the ad in this way, Miško accepts the view of heterosexuality as the norm, against which nonnormative identities have to be negotiated.

The concept of masculinity, however, cannot be understood on its own and is fundamentally relational (Coates 2003). Masculinity is mainly posited as the direct opposite of femininity and is socially meaningful only when understood in relation to femininity. The construction of hegemonic categories crucially relies on such processes of opposition and differentiation (Kiesling 2006). Ads such as (1) reveal how dominant masculinities are constructed in the very gay community, by drawing on the opposition to subordinated categories of effeminate gay men.

The analysis of the GaySerbia ads suggests that language is here used to create a cohesive community in which masculinity is prized and effeminacy othered and stigmatized. Marginalization of effeminacy is effected through various linguistic means, while also echoing traces of the heteronormative discourse. The following sections describe the linguistic practices used to this effect.

\subsection{Discourse Features and Lexical Choices}

In the wording of the ads, the group's ideology of desirable masculinity is produced and reproduced stylistically. The process is essentially indexical, as the writers construct their identities drawing on discourse features and lexical choices that are ideologically associated with masculinity. This is not to say that any such features are distinctively masculine, but they index masculinity via stances such as directness, assertiveness or forcefulness, that have ideologically acquired the social meaning of masculinity. The following ad is a typical example:

(3) Caza: Treba da izgledaš kao muško, a ne kao pička, još bolje da nemaš iskustvo jer ga nemam ni ja...bez lažova i starijih, pošto ovde slabo zalazim javite se na mail ili msn. 


\section{Ksenija Bogetić}

'Caza: You should look like a man and not like a sissy, it is even better if you are inexperienced because so am I...no liars or older guys, as I don't come here often contact me by email or msn.'

Caza is very direct and factual in describing what he wants. He starts his ad with a direct reference to masculine appearance and discourages non-masculine people from responding, using a value-laden word sissy. His ad is composed in a way that aligns him with the norms prescribing 'acceptable maleness' (Coates 2003), while non-masculine men are constructed as inferior and undesirable.

Moreover, masculinity is here also indexed indirectly, by the choice of lexis and discourse features. In this ad, as in the majority of other ads on the site, the discourse style is non-expressive and non-cooperative. It involves no emoticons, such as smilies, so frequent in computer-mediated communication; no capital letters for shouting, no multiple punctuation marks, no trace of expressiveness in writing that tends to be associated with the feminine style. The style is also notably non-cooperative. The language of inclusion that draws on assumed shared knowledge and experiences, sometimes described as typical in gay speech (Leap 1996), is almost entirely absent here. There are generally no references to gay culture, and humorous remarks are very uncommon. The ads typically contain no hedges and very scarce discourse markers that would facilitate communication. One discourse marker that does, however, appear in several ads is brate, similar in meaning to the English dude, which is again traditionally associated with heterosexual masculinity. Also, bad words and swearing, which seem to have a stereotypical association with masculinity (Mills 2008), are fairly common in the ads.

\subsection{Negation}

One direct way of distancing from the homosexual stereotype is effected through the use of negation. Apparently, this is nothing surprising, but what makes it worth mentioning is its consistency: in the entire corpus, lexical elements denoting effeminacy and lack of masculinity are always used in the negative form, never in the positive. The following are just a couple of random examples:

Niki: Normalan sam, nisam feminiziran, volim sex sa starijim momcima, $i$ intimno druženje.

'Niki: I am normal, not effeminate, I like sex with older guys and intimate friendship.'

Sladakk: Tražim momka do $20 \mathrm{~g}$ s kim bih prvi put probao seks sa muškarcem. Samo da nisi feminiziran i debeo. Piši na mail-

'Sladakk: Looking for a guy up to 20 years of age, with whom I would have sex with a man for the first time. As long as you're not effeminate and fat. Email me at-'

In fairly concise ads, both writers stress non-effeminacy in self-description or the description of the ideal other. What is more, examples like (4) suggest that being 


\section{Heteronormative Discourse in Personal Ads}

not effeminate is in this community directly related to being normal, an adjective repeatedly used in descriptions. ${ }^{1}$

\subsection{Coordination}

The analysis of lexical elements used in coordination can also reveal prevalent ideologies of the ad-writers. It has been noted before that analyzing collocations of words can yield social information, as the company that words keep can have an indirect effect on the meaning of these terms (e.g. Mills 2008, Romaine 2001). Hunston (2002) notes that collocation can convey meaning implicitly and even be at odds with what is expressed overtly. Romaine further argues that:

\footnotetext{
"[...] connotations of words do not arise from words themselves but from how they are used in context. The meanings of words are constructed and maintained by patterns of collocation. Collocations transmit cultural meanings and stereotypes which have built up over time" (Romaine 2001:160, cited in Mills 2008).
}

One common form of collocation is coordination, although, as a separate process, it has received comparably less attention in this kind of research. Coordination, especially conjunction, involves an even firmer associative relationship between the elements. Generally speaking, in these constructions, coordinated elements tend to get the same evaluative judgement. More importantly, repeatedly occurring and almost fixed coordinate phrases, such as the ones found in the ads collected, may reflect cognitive associations that exist in a particular culture. As such, coordination can feature as a useful instrument in discursive construction of social groups.

The analysis of coordination in the corpus gives a clear insight into the dominant values of the personals. Effeminate, for instance, is typically coordinated with negative physical attributes, but also with undesirable psychological traits. Looking more closely at the coordinate elements occurring with the properties of being effeminate or non-effeminate, we find an invariable formula: words denoting effeminacy are consistently coordinated with negative traits, while those denoting non-effeminacy coordinate with positive traits. The following examples offer some illustration:

(6) SM: Što se izgleda tiče, mogao bih da kažem da sam zgodan i nefeminiziran, mada mi izgled i nije toliko bitan. [...]

'SM: As far as looks are concerned, I could say that I am handsome and non-effeminate, though looks don't matter that much to me. [...]'

(7) Ivannn: [...] Ne nekog perverznog, feminiziranog, lažljivog, prevrtljivog, vec šarmantnog, slatkog $i$ veselog.

\footnotetext{
1 'Normal' in Serbian primarily means 'mentally healthy' and does not contain the English meaning 'usual, typical'.
} 


\section{Ksenija Bogetić}

'Ivannn: [...] Not someone perverted, effeminate, lying, cheating, but someone charming, cute and cheerful.'

Shvrle: [...] Tebe zamišljam kao lepog mladog i pametnog dečka koji nije feminiziran ili isfoliran, koji zna šta hoće.

'Shvrle: [...] I imagine you as a handsome, young and smart guy who is not effeminate or fake, who knows what he wants.'

As the examples show, associations go beyond physical attributes to include a whole range of other traits. Effeminacy, a property mentioned in nearly all the ads collected, gets associated with lexical fields of various negative terms. Table 1 below lists the five properties that are by far most commonly associated with the words effeminate and fem, along with some expressions that were actually used (the Serbian words used are given in their approximate English translation, for the purpose of visual clarity):

Table 1: top five properties coordinated with effeminate

\begin{tabular}{|l|l|}
\hline 1. insane & insane, deranged, disturbed, crazy, mad, lunatic \\
\hline 2. unattractive & bad-looking, ugly, scag, fat \\
\hline 3. promiscuous, perverted & promiscuous, perverted, pervert, kinky \\
\hline 4. insincere, dishonest & dishonest, lying, cheating, liar, fake \\
\hline 5. dirty & dirty, filthy \\
\hline
\end{tabular}

Interestingly, the top of the list is not even unattractive, but insane. At first glance it appears hard to see the common semantic relationship between the given adjectives, namely how being effeminate relates to properties such as perversion or dishonesty. However, the instances of coordination are far from accidental. These are precisely the most common accusations directed against homosexuals by the public in Serbia, or even by the church - those related to perversion and insanity are actually common arguments of the Serbian orthodox church. In the discourse of church officials gay men tend to be constructed as mentally ill, in need of help to be cured and returned to the right paths of fatherhood and family life. Issues of sexuality also resonate in nationalist discourses, with political or religious leaders drawing on them in order to solidify their credibility as keepers of traditional values of the nation.

Coordination can thus reflect such culture-specific associations, reproduced in the construction of sexual and social identities. Its patterns of usage index, albeit indirectly, traces of the heteronormative discourse, together with notions of appropriate masculinity. Furthermore, coordination here reveals one subtle strategy by which the stigma associated with homosexuality is in this community shifted only to one its subgroup, effeminate homosexuals. 


\section{Heteronormative Discourse in Personal Ads}

\subsection{Slang}

Slang is present to a great degree in the ads as a productive means of constructing identity through language. On one hand, these slang words have a unifying function, indexing a stance of modernity, coolness and involvement in the global youth culture. On the other hand, slang is a means of social differentiation, serving as an in-group marker (Bucholtz 2006). Many of the slang terms used here would be completely incomprehensible to people outside of this community, especially those related to sexual practices and sex roles.

A significant property of slang in general is that it is highly value-laden, commonly involving forceful stance-taking such as positive or negative evaluation (Bucholtz 2006). In the personal ads analyzed, this property is evident mainly in the ways writers draw on it as a resource for ridiculing effeminacy and celebrating masculinity, which also enables them to align with the locally constructed values. We come across a myriad of derogative names for the effeminate gay men which stylistically reproduce the group's ideology. A substantial number of these terms encompasses derivatives produced from the stem word fem, a term that features as the most common slang word in the ads. Morphological processes often involve derivation using suffixes that add diminutive or pejorative meaning (e.g. femiša, femko, femonja, all roughly translatable as femmy). Others correspond to the English value-laden terms like sissy, and are commonly used in opposition to words denoting masculinity, as was shown in (3).

An interesting mechanism employed here is semantic narrowing, the narrowing of meaning of particular insulting slang terms for homosexuals. The most common example is the word tetka, similar to the English auntie, as well as several other common derogative words meaning "gay". As part of this process, the scope of reference is narrowed to denote only effeminate homosexuals, while the new meaning remains just as value-laden as the original one. This mechanism also illustrates the shifting of stigma from the community as a whole only to its effeminate members.

Ad-writers can thus draw on slang strategically in order to achieve particular social goals and display desired sexual and social identities. In the example (9) below, PejaXX uses a lot of modern slang words associated with youth and coolness. He then goes on to say that he is "not fem and hates that." This lexical choice enables him to affirm his identity as someone enculturated with the community and familiar with its vocabulary. Furthermore, his statement involves direct stance-taking towards effeminacy.

(9) PejaXX: Izgled mi nije primaran ali u najmanju ruku je potrebno da si prosek jer ni ja nisam gabor. Takodje ne podnosim iskompleksirane tipove $i$ degene koji su utripovani a ne znaju ni nos da obrišu. Nisam fem i to mrzim... Trenirao sam tenis 8 godina...čisto da spomenem to i ovde.

'Peja XX: Looks aren't crucial, but you should at least be average, because I'm not a dogface either. I also can't stand self-hating dudes and wankers 


\section{Ksenija Bogetić}

who are stuck up but can't even wipe their own noses. I'm not fem and I hate that ... I played tennis for 8 years ... just thought I should mention it here.'

The ad adequately illustrates the multiple social purposes for which slang is used among these adolescents. It is possible to identify its three basic functions here: signaling belonging to the youth culture in general, signaling belonging to the gay subculture, and last but not least, asserting a negative stance towards effeminacy.

Importantly, apart from the fairly original fem-derivatives, the slang terms used here for effeminate gay men are the same as those used in heterosexist discourses for describing any men deviating from the prescribed notions of masculinity. Slang thus still features as a resource for legitimating particular social identities while marginalizing others. As such evaluations are repeated, discourses of heteronormativity are reworked within the very gay community.

\section{Discussion and Conclusions}

The present study has explored some aspects of language and teenage identity online, and showed how group ideology can be produced stylistically - through discourse features and lexical choices, grammar and slang. A central process in the creation and performance of identities is that of indexicality, which in most cases operates indirectly, mediated by highly local processes of shared representations. The online material has proved fruitful for investigating such indexical relations. It has shown that most prominent local values of the teenage ad-writers involve masculinity, while effeminacy is excluded and marginalized. Thus, in the wording of the GaySerbia ads not only sexual, but also sociocultural identities are displayed, together with the entire complex web of stances, styles, identities and social representations. The ads also indirectly reveal the ways in which sexuality is regulated by hegemonic heterosexuality and normative ideologies, which points to the need for studying sexuality as a wider sociocultural phenomenon.

The study supports the view of language as ideologically marked. It shows that patterns in language use can reveal ideological constructs, pointing to attitudes and social representations that may not be expressed overtly. However, the analysis also demonstrates that language does not figure only as a tool for reproducing reality, that it is also constructive of social reality. As associations between concepts are built, new discourses and new identities are constructed. The repetition of the two most frequently encountered coordinate phrases, non-effeminate and handsome and normal and non-effeminate, for instance, leave the teenage adwriters or readers habituated to certain ways of talking or thinking that they can rely on, consciously or not, in constructing their own identities. It is in this way that the identity of a 'masculine and non-effeminate gay man' emerges as unquestionably desirable and worth striving for. As the described images are evoked repeatedly, discourses and identities are reworked within the community.

One of the underlying concepts evoked through the linguistic practices analyzed is that of hegemony. Rather than representing a challenge to normative 


\section{Heteronormative Discourse in Personal Ads}

heterosexuality and concepts of masculinity, the young gay community in Serbia appears still structured by the hegemonic discourses of masculinity and heterosexuality. The ads illustrate the Gramscian concepts of hegemony as a process of leadership through which subordinate groups consent to their own subordination, adopting the imposed external values. This raises the more general questions of the maintenance of power in contemporary society. Distinct from the past statelegislative or police intervention, hegemony operates in more subtle ways, by controlling the ideologies and discourses extant in society. Consequently, norms are internalized as given and no longer recognized as culturally produced. The GaySerbia ads are illustrative of the process, showing how discourses of masculinity and heteronormativity are re-made within the gay community. Constructing effeminate gay man as 'the other' is a discursive strategy that allows the adwriters to position themselves as dominant and closer to the accepted ideals of masculinity. However, by perpetuating the normative discourses, the gay culture ultimately allows its own marginality to be maintained.

All this has some implications for sociolinguistic study of sexuality and gender. It is evident that 'sexuality is not just about sex' (Eckert 2002:109), but is socially structured and as such should be observed as imbricated in cultural norms and power relations.

Importantly, the analysis of GaySerbia ads problematizes the concept of a singular Gay Speech, as well as the concept of a pre-defined social category 'gay' that can be observed in correlationist studies. The findings demonstrate the ways that the young ad-writers use linguistic resources to construct identities in opposition to the stereotypical features ideologically associated with gay speech and gay behaviour. This points to the importance of distinguishing between ideology and practice in studies of identity and avoiding the tempting tendency to simplify a sociolinguistic field. For instance, arguing that Gay Men's English is based on principles of cooperative discourse (Leap 1996) is bound to fall short of capturing the multifaceted nature of gay styles. Findings in this study actually suggest the very opposite: the discourse style of the analyzed personal ads is notably noncooperative. This points to the need to explore the ideological processes through which the relation of certain linguistic features with particular social groups is formed, rather than simply correlate variables with reified social categories.

\section{References}

Barrett, Rusty. 1997. The 'Homo-Genius' speech community. In A. Livia and K. Hall, eds., Queerly phrased: Language, gender, and sexuality. New York: Oxford University Press.

Barrett, Rusty. 2002. Is queer theory important for sociolinguistic theory? In Campbell-Kibler et al. (2002), 25-43. Stanford, CA: CSLI. 


\section{Ksenija Bogetić}

Bucholtz, Mary. 2006. Word up: Social meanings of slang in California youth culture. In J. Goodman and L. Monaghan, eds., A cultural approach to interpersonal communication: Essential readings, 243-267. Malden, MA: Blackwell.

Bucholtz, Mary, and Kira Hall. 2004. Theorizing identity in language and sexuality research. Language in Society 33:501-547.

Campbell-Kibler, K., R. J. Podesva, S. J. Roberts, and A. Wong, eds. 2002. Language and sexuality: Contesting meaning in theory and practice. Stanford, CA: CSLI.

Coates, Jennifer. 2003. Men talk: Stories in the making of masculinities. Malden, MA: Blackwell Publishing.

Connel, Raewyn. 1987. Gender and power. Sydney: Allan and Unwin.

Connel, Raewyn. 1995. Masculinities. Cambridge: Polity Press.

De Fina, A., D. Schiffrin, and M. Bamberg, eds. 2006. Discourse and identity. Cambridge: Cambridge University Press.

Eckert, Penelope. 2002. Demystifying sexuality and desire. In Campbell-Kibler et al. (2002), 99-110. Stanford, CA: CSLI.

Gramsci, Antonio. 1994. Pre-prison writings. ed. Richard Bellamy, trans. Virginia Cox. New York: Cambridge University Press.

Hunston, Susan. 2002. Corpora in applied linguistics. Cambridge: Cambridge University Press.

Kiesling, Scott. 2006. Hegemonic identity-making in narrative. In De Fina et al. (2006), 261-288. Cambridge: Cambridge UP.

Leap, William. 1996. Word's out: Gay Men's English. Minneapolis: University of Minnesota Press.

Livia, Anna. 2002. Camionneuses s'abstenir: Lesbian community creation through the personals. In Campbell-Kibler et al. (2002), 191-206. Stanford, CA: CSLI.

Mills, Sara. 2008. Language and sexism. Cambridge: Cambridge University Press.

Ochs, Elinor. 1992. Indexing gender. In A. Duranti and C. Goodwin, eds., Rethinking context: Language as an interactive phenomenon, 335-358. Cambridge: Cambridge University Press.

Romaine, Suzanne. 2001. A corpus-based view of gender in British and American English. In M. Hellinger and H. Bussmann, eds., Gender across languages. The de/construction of gender roles through language variation and change, 153-176. Amsterdam: John Benjamins.

Ksenija Bogetić

26 Vojvode Stepe

11000 Belgrade

Serbia

ksenija.bogetic@gmail.com 